\title{
Jurnal Sains dan Kesehatan
}

Journal homepage: https://jsk.farmasi.unmul.ac.id

\section{Hubungan antara Penyakit Arteri Perifer dan Kadar HbA1c dengan Tindakan Amputasi Ekstremitas pada Pasien Ulkus Kaki Diabetik di RSUD Abdul Wahab Sjahranie Samarinda}

\author{
Relationship between Peripheral Arterial Disease and HbA1c Levels \\ with Amputation of Extremities in Diabetic Foot Ulcer Patients \\ at Abdul Wahab Sjahranie Hospital Samarinda
}

\author{
Ayu Wira Oktalia*, Yuliana Rahmah Retnaningrum, Siti Khotimah
}

Fakultas Kedokteran Universitas Mulawarman, Samarinda, Indonesia

*Email korespondensi: ayuwira.oktalia@gmail.com

\begin{abstract}
Abstrak
Ulkus kaki diabetik adalah luka kronik pada daerah di bawah pergelangan kaki, yang meningkatkan morbiditas, mortalitas, dan mengurangi kualitas hidup pasien. Prevalensi penderita diabetes melitus dengan ulkus kaki diabetik di Indonesia sekitar 15\% dan angka amputasi penderita ulkus kaki diabetik 30\%. Dengan mengontrol kadar HbA1c, perkembangan neuropati diabetik dan penyakit arteri perifer yang merupakan faktor risiko amputasi ektremitas dapat dicegah. Penelitian ini bertujuan untuk mengetahui ada tidaknya hubungan antara penyakit arteri perifer dan kadar HbA1c dengan tindakan amputasi ekstremitas pada pasien ulkus kaki diabetik di RSUD Abdul Wahab Sjahranie Samarinda. Desain penelitian yang digunakan adalah studi analitik observasional potong lintang dengan pendekatan retrospektif. Sampel dipilih secara acak sederhana sebanyak 49 sampel. Data sampel diperoleh dari data rekam medis di RSUD Abdul Wahab Sjarharnie tahun 2017-2020. Uji statistik yang digunakan adalah uji fisher dan uji chi-square. Hasil penelitian ini menunjukkan bahwa tindakan amputasi pada pasien ulkus kaki diabetik memilki hubungan yang signifikan secara statistik dengan penyakit arteri perifer $(\mathrm{p}=0,022$; $\mathrm{PR}=2,925 ; 95 \% \mathrm{CI}=1,316-6,501)$ dan kadar HbA1c $(\mathrm{p}=$ $0,024 ; \mathrm{PR}=4,138 ; 95 \% \mathrm{CI}=1,037-16,519)$.
\end{abstract}

Kata Kunci: ulkus kaki diabetik, penyakit arteri perifer, HbA1c 
Hubungan antara Penyakit Arteri Perifer dan Kadar HbA1c dengan Tindakan Amputasi Ekstremitas pada Pasien Ulkus Kaki Diabetik di RSUD Abdul Wahab Sjahranie Samarinda

\begin{abstract}
Diabetic foot ulcers are chronic sores in the area below the ankles, which increase morbidity, mortality, and reduce the patient's quality of life. The prevalence of diabetes mellitus patients with diabetic foot ulcers in Indonesia is around 15\% and the amputation rate for diabetic foot ulcers is $30 \%$. By controlling HbA1c levels, the development of diabetic neuropathy and peripheral artery disease which are risk factors for amputation of extremity can be prevented. This study aims to determine whether there are association between peripheral artery disease and HbA1c levels with extremity amputation in diabetic foot ulcer patients at RSUD Abdul Wahab Sjahranie Samarinda. The research design used was analytical cross-sectional study with a retrospective approach. The sample was selected by simple random sampling as many as 49 samples. The sample data was obtained from medical record data at RSUD Abdul Wahab Sjarharnie in 2017-2020. The statistical test used was fisher's test and chi-square test. The results of this study indicated that amputation in diabetic foot ulcer patients had a statistically significant association with peripheral artery disease $(\mathrm{p}=0.022$; PR $=2.925 ; 95 \% \mathrm{CI}=1,316-6,501)$ and HbA1c levels $(\mathrm{p}=0.024 ; \mathrm{PR}=4.138 ; 95 \% \mathrm{CI}=1.037-16.519)$.
\end{abstract}

Keywords: diabetic foot ulcer, peripheral artery disease, HbA1c

DOI: https://doi.org/10.25026/jsk.v3i5.641

\section{Pendahuluan}

Ulkus kaki diabetik adalah luka kronik pada daerah di bawah pergelangan kaki, yang meningkatkan morbiditas, mortalitas, dan mengurangi kualitas hidup pasien [1]. Ulkus kaki diabetik disebabkan oleh proses neuropati perifer, penyakit arteri perifer (peripheral arterial disease), ataupun kombinasi keduanya [2].

Prevalensi dari ulkus kaki diabetik bervariasi antara $1 \%$ dibeberapa penelitian di Eropa dan Amerika Utara sampai 11\% pada laporan di beberapa negara Afrika. Di hampir semua negara berkembang, insidensi tahunan dari ulkus kaki diabetik di antara penderita diabetes sekitar $2 \%$ dan sekitar $1 \%$ dari penderita diabetes mengalami amputasi ekstremitas bawah [3]. Prevalensi penderita diabetes melitus dengan ulkus kaki diabetik di Indonesia sekitar 15\%. Angka amputasi penderita ulkus kaki diabetik 30\%, angka mortalitas penderita ulkus kaki diabetik 32\% dan ulkus kaki diabetik merupakan sebab perawatan rumah sakit yang terbanyak sebesar 80\% untuk diabetes melitus [4].

Dalam usaha untuk mengobati ulkus iskemik dan neuropatik, terkadang ekstremitas bawah tidak dapat diselamatkan and amputasi tidak dapat dihindar. Indikasi dari amputasi pasien dengan diabetes biasanya akibatkan oleh ulkus yang tidak dapat sembuh, atau seringnya terjadi gangren dan infeksi yang terjadi secara bersamaan [5]. Dari klasifikasi tindakan operasi kaki diabetik, amputasi adalah tindakan operasi kelas III kuratif untuk membantu penyembuhan luka terbuka atau kelas IV emergensi untuk membatasi perkembangan dari infeksi [6]. Namun pada keadaan ulkus yang sulit dikelola dan adanya penyakit arteri perifer, amputasi sebagai tindakan operasi elektif sebaiknya dipertimbangankan dalam pemilihan perawatan [7].

Berdasarkan penelitian yang dilakukan di Rumah Sakit Umum Dr. Kariadi Semarang, Faktor resiko independen yang dapat menyebabkan amputasi ekstremitas bawah pada pasien ulkus kaki diabetik adalah kadar HbA1c $\geq 8 \%$, adanya penyakit arteri perifer, hipertrigliseridemia, dan hipertensi [8].

Penyakit arteri perifer (peripheral arterial disease/PAD) merupakan kondisi aterosklerosis yang terjadi pada arteri selain arteri koroner. Penyempitan hingga oklusi pembuluh darah menyebabkan penurunan 
suplai darah ke tungkai [9]. Pasien diabetes memiliki penyakit arteri perifer yang lebih parah dibanding pasien tanpa diabetes [10]. Penyakit arteri perifer dapat menyebabkan gangren dan amputasi kaki jika tidak ditangani [11]

Salah satu pengendalian diabetes melitus adalah dengan pemeriksaan kadar HbA1c. Nilai pemeriksaan HbA1c dijadikan gold standar untuk penilaian kadar glukosa darah karena selama 8-10 minggu terakhir akan meningkat secara proposional. Peningkatan kadar HbA1c yang berkepanjangan, menyebabkan tes HbA1c sebagai pemeriksaan akurat untuk menilai status glikemik jangka panjang sehingga dapat digunakan sebagai prediktor terhadap kemungkinan terjadinya komplikasi. Hasil penelitian dari the United Kingdom Prespective Diabetes Study (UKPDS), menunjukkan setiap penurunan $1 \%$ dari HbA1c akan menurunkan komplikasi sebesar 35\%. Peningkatan kadar HbA1c $>7 \%$ mengindikasikan diabetes melitus yang tidak terkendali dan beresiko tinggi untuk timbulnya komplikasi kronik termasuk kaki diabetik $[1,12]$.

\section{Metode Penelitian}

\subsection{Desain Penelitian}

Desain penelitian yang dipakai adalah studi analitik observasional potong lintang (cross-sectional) dengan pendekatan retrospektif. Desain ini digunakan untuk mengetahui hubungan antara penyakit arteri perifer dan kadar HbA1c dengan tindakan amputasi ekstremitas pada pasien ulkus kaki diabetik di RSUD Abdul Wahab Sjahranie Samarinda. Penelitian ini dilaksanakan di Ruang Rekam Medik Rawat Inap dan Rawat Jalan RSUD Abdul Wahab Sjahranie Samarinda.

\subsection{Sampel Penelitian}

Sampel penelitian adalah seluruh pasien yang didiagnosis diabetes melitus dengan komplikasi ulkus kaki diabetik di RSUD Abdul Wahab Sjahranie Samarinda tahun 2017-2020 yang memenuhi kriteria inklusi penelitian sebanyak 49 sampel dengan metode pengambilan sampel acak sederhana (Simple random sampling) yang memenuhi kriteria inklusi dari data rekam medis pasien yang dirawat inap dan rawat jalan.

Untuk kriteria inklusinya adalah sebagai berikut: 1) Pasien yang didiagnosis diabetes melitus dengan komplikasi ulkus kaki diabetik oleh dokter spesialis penyakit dalam RSUD Abdul Wahab Sjahranie Samarinda, 2) Untuk pasien yang sudah melakukan tindakan amputasi harus dilakukan oleh dokter spesialis bedah thoraks dan kardiovaskuler atau dokter spesialis orthopedi dan traumatotologi RSUD Abdul Wahab Sjahranie Samarinda, termasuk dalam tindakan amputasi ekstremitas minor atau mayor dan termasuk tindakan operasi kuratif atau emergensi. Kriteria ekslusinya adalah pasien dengan data rekam medis yang tidak lengkap atau tidak mencantumkan variabel yang diteliti dan tidak bisa dibaca.

\subsection{Definisi Operasional}

Tindakan Amputasi ekstremitas adalah tindakan memisahkan sebagian atau seluruh bagian kaki pada pasien ulkus kaki diabetik (ICD-10 E11.5) yang dilakukan oleh dokter spesialis bedah umum, dokter spesialis bedah toraks dan kardiovaskular atau dokter spesialis ortopedi dan traumatologi di RSUD Abdul Wahab Sjahranie Samarinda dan tercatat dalam rekam medis. Kriteria objektif : 1) Ya : dilakukannya prosedur amputasi pada pasien kaki diabetik baik mayor ataupun minor, 2) Tidak : Tidak dilakukannya prosedur amputasi pada pasien kaki diabetik baik mayor ataupun minor

Penyakit Arteri Perifer adalah Penyempitan hingga oklusi pembuluh darah menyebabkan penurunan suplai darah ke tungkai bawah yang telah didiagnosa sesuai dengan kode ICD-10 I73.9 oleh dokter spesialis penyakit dalam atau dokter spesialis bedah toraks dan kardiovaskular di RSUD Abdul Wahab Sjahranie Samarinda dan tercatat dalam rekam medis. Kriteria Objektif: 1) Tidak: Pasien tidak terdiagnosa dengan penyakit arteri perifer, 2) Ya : Pasien terdiagnosa dengan penyakit arteri perifer

Kadar HbA1c adalah Kadar hemoglobin sel darah merah yang mengikat glukosa sebagai petunjuk kontrol glikemik pasien diambil pada saat masuk rumah sakit sebelum melakukan tindakan amputasi untuk pasien yang telah 
melakukan amputasi dan hasil pemeriksaan kadar HbA1c terakhir bagi pasien yang belum melakukan tindakan amputasi ektremitas di RSUD Abdul Wahab Sjahranie Samarinda dan tercatat dalam rekam medis. Kriteria Objektif: 1) Terkontrol : $<8 \%, 2$ ) Tidak Terkontrol : $\geq 8 \%$

\subsection{Analisis Data}

Analisis data dengan menggunakan analisis data univariat dan bivariat. Analisis data univariat dilakukan dengan penyajian tabel frekuensi, sementara analisis bivariat digunakan untuk menjelaskan signifikansi secara statistik hubungan antara variabel menggunakan metode chi-square dan fisher

\section{Hasil dan Pembahasan}

Tabel 1 Gambaran Umum Pasien Ulkus Kaki Diabetik

\begin{tabular}{lll}
\hline Karakteristik & Jumlah & Persentase (\%) \\
\hline Usia : & 1 & 2,0 \\
$25-34$ & 14 & 28,6 \\
$35-44$ & 14 & 28,6 \\
$45-54$ & 9 & 18,4 \\
$55-64$ & 9 & 18,4 \\
$65-74$ & 2 & 4,1 \\
$\geq 75$ & 49 & 100 \\
\hline Total & & \\
\hline Jenis Kelamin : & 17 & 34,7 \\
Laki-Laki & 32 & 65,3 \\
Perempuan & 49 & 100 \\
\hline Total & & \\
\hline Penyakit Arteri Perifer & 10 & 20,4 \\
Ya & 39 & 79,6 \\
Tidak & 49 & 100 \\
\hline Total & & \\
\hline Kadar HbA1c & 20 & 40,8 \\
Terkontrol & 29 & 59,2 \\
Tidak Terkontrol & 49 & 100 \\
\hline Total & 14 & 28,6 \\
\hline Tindakan Amputasi & 35 & 71,4 \\
Ya & 49 & 100 \\
Tidak & & \\
\hline Total & & \\
\hline
\end{tabular}

Pasien ulkus kaki diabetes terbanyak adalah pada kelompok usia 35 - 44 dan 45 - 54 tahun yaitu masing-masing sebanyak 14 pasien $(28,6 \%)$ dan kelompok usia dengan jumlah terendah yaitu 25 - 34 tahun sebanyak 1 pasien (2\%). Distribusi pasien berdasarkan jenis kelamin didominasi oleh jenis kelamin perempuan sebanyak 32 pasien $(65,3 \%)$ dan laki-laki sebanyak 17 pasien (34,7\%). Distribusi pasien dengan penyakit arteri perifer terdapat 10 pasien $(20,4 \%)$ dengan komplikasi penyakit arteri perifer dan 39 pasien $(79,6 \%)$ tanpa komplikasi penyakit arteri perifer. Distribusi Pasien dengan kadar HbA1c yang tidak terkontrol sebanyak 29 pasien $(59,2 \%)$ dan 20 pasien $(40,8 \%)$ yang terkontrol. Distribusi pasien yang telah melalui tindakan amputasi sebanyak 14 pasien $(28,6 \%)$ dan 35 pasien $(71,4 \%)$ yang hanya melalui tindakan debridement, nekrotomi atau angioplasti.

Analisis bivariat antara penyakit arteri perifer dengan tindakan amputasi pada pasien ulkus kaki diabetik dilakukan dengan uji fisher. Hasil uji fisher pada tabel di atas menunjukkan nilai $\mathrm{p}=0,022$, nilai ini lebih kecil dari $0,05(\mathrm{p}<$ $0,05)$. Nilai Prevalence Ratio pada analisis ini adalah 2,925 yang artinya, pasien ulkus kaki diabetik dengan komplikasi penyakit arteri perifer berisiko mengalami tindakan amputasi ekstremitas sebesar 2,925 kali dibandingkan pasien tanpa komplikasi penyakit arteri perifer dengan nilai 95\% Confidence Interval 1,316 6,501 .

Hasil penelitian ini sejalan dengan penelitian yang dilakukan oleh Ugwu, et al. [13] tentang prediktor dari amputasi ektremitas bawah pada pasien dengan ulkus kaki diabetik didapatkan bahwa terdapat hubungan antara penyakit arteri perifer dengan amputasi ektremitas bawah dengan nilai $\mathrm{P}<0,001$. Hasil yang sama juga didapatkan dalam penelitian Pemayun et al. [8] mengenai faktor risiko amputasi ektremitas bawah pada pasien ulkus kaki diabetik yang dilakukan di Rumah Sakit Umum Pusat Dr. Kariadi Semarang, terdapat hubungan antara penyakit arteri perifer dengan tindakan amputasi ektremitas bawah dengan nilai $\mathrm{p}=0,009$.

Penyakit arteri perifer adalah manifestasi dari aterosklerosis dari arteri pada ektremitas bawah yang menghasilkan oklusi pada arteri. Pada penyakit arteri perifer, terdapat penimbunan deposit lemak pada dinding arteri. Deposit lemak ini akan mempersempit lumen arteri menyebabkan stenosis dan mengurangi aliran darah untuk area yang disuplai oleh pembuluh darah tersebut [14]. Pengurangan aliran darah bisa menyebabkan penyembuhan luka menjadi lambat dan membuat tubuh menjadi kurang efektif dalam melawan virus. Hal ini mengakibatkan kerusakan atau kematian 
jaringan dan dapat meyebar pada tulang, jika infeksi tidak diobati, amputasi dapat mengurangi penyebaran kerusakan jaringan [15]. Hasil meta analisis yang dilakukan oleh Septiani, Rahardjo, \& Prasetya [16] pasien ulkus kaki diabetik dengan penyakit arteri perifer 2,46 kali lebih besar kemungkinan untuk amputasi dibandingkan pasien tanpa penyakit arteri perifer.

Tabel 2 Tabulasi Silang Penyakit Arteri Perifer dan Tindakan Amputasi Ektermitas

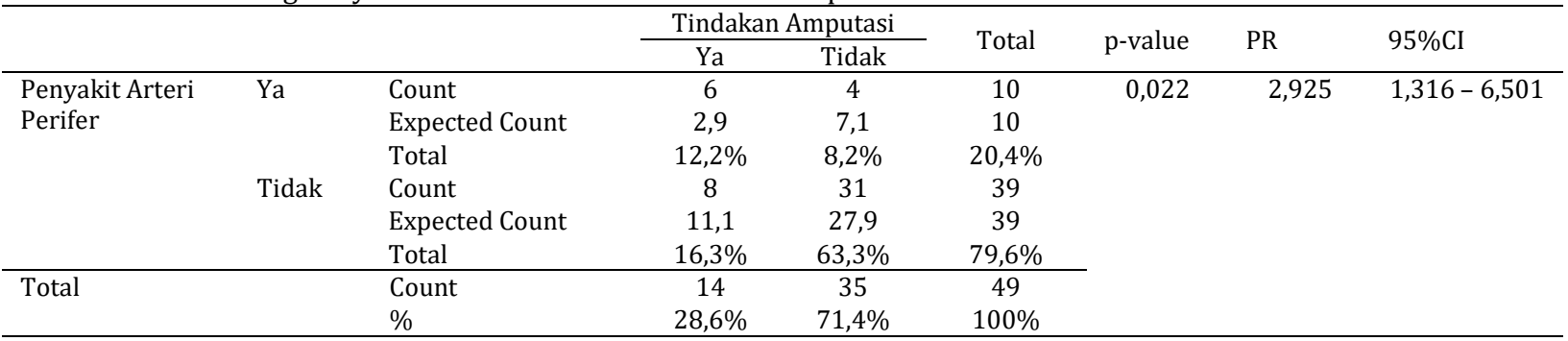

Tabel 3 Tabulasi Silang Kadar HbA1c dan Tindakan Amputasi Ektermitas

\begin{tabular}{|c|c|c|c|c|c|c|c|c|}
\hline & & & \multicolumn{2}{|c|}{ Tindakan Amputasi } & \multirow[b]{2}{*}{ Total } & \multirow[b]{2}{*}{$\mathrm{p}$-value } & \multirow[b]{2}{*}{ PR } & \multirow[b]{2}{*}{$95 \%$ CI } \\
\hline & & & $\mathrm{Ya}$ & Tidak & & & & \\
\hline \multirow[t]{6}{*}{ Kadar HbA1c } & Tidak & Count & 12 & 17 & 29 & 0,024 & 4,138 & $1,037-16,519$ \\
\hline & Terkontrol & Expected Count & 8,3 & 20,7 & 29 & & & \\
\hline & & Total & $24,5 \%$ & $34,8,2 \%$ & $59,2 \%$ & & & \\
\hline & Terkontrol & Count & 2 & 18 & 20 & & & \\
\hline & & Expected Count & 5,7 & 14,3 & 20 & & & \\
\hline & & Total & $4,1 \%$ & $36,7 \%$ & $40,8 \%$ & & & \\
\hline \multirow[t]{2}{*}{ Total } & & Count & 14 & 35 & 49 & & & \\
\hline & & $\%$ & $28,6 \%$ & $71,4 \%$ & $100 \%$ & & & \\
\hline
\end{tabular}

Namun hasil penelitian ini tidak sejalan dengan penelitian yang dilakukan oleh Beaney, Nunney, Gooday, \& Dhatariya [17] mengenai faktor-faktor yang menentukan risiko dari amputasi kaki diabetik memberikan hasil dimana penyakit arteri perifer tidak memiliki hubungan dengan amputasi kaki diabetik yang signifikan secara statistik dengan nilai $\mathrm{p}=0,811$, walaupun dalam penelitian juga menindikasi bahwa risiko amputasi berkurang pada pasien tanpa penyakit arteri perifer.

Perbedaan dari hasil penelitian oleh Beaney et al. [17] dapat dikarenakan perbedaan metode penelitian yang digunakan. Metode yang digunakan adalah analitik observasional kohort dengan pendekatan retrospektif, metode ini memiliki keunggulan dibanding metode cross-sectional yang dilakukan oleh peneliti. Studi kohort merupakan desain terbaik dalam menentukan insidens, perjalanan penyakit dan dapat menerangkan hubungan temporal antara faktor risiko dan efek [18]. Namun tetap ada keterbatasan yang tetap dialami Beaney et al. [17], yaitu sampel yang relatif kecil untuk studi kohort 165 subjek termasuk 33 pasien yang melakukan amputasi sehingga dibutuhkan studi dengan pendekatan prospektif untuk memvalidasi temuan pada penelitian ini. Selain itu kurangnya randomisasi sampel penelitian meningkatkan bias seleksi.

Analisis bivariat antara kadar HbA1c dengan tindakan amputasi pada pasien ulkus kaki diabetik dilakukan dengan uji chi-square. Hasil uji chi-square pada tabel di atas menunjukkan nilai $\mathrm{p}=0,024$, nilai ini lebih kecil dari 0,05 $(\mathrm{p}<0,05)$. Nilai Prevalence Ratio pada analisis ini adalah 4,138 yang artinya, pasien ulkus kaki diabetik dengan kadar HbA1c tidak terkontrol berisiko mengalami tindakan amputasi ekstremitas sebesar 4,138 kali dibandingkan pasien yang memiliki kadar HbA1c terkontrol dengan nilai 95\% Confidence Interval 1,037 - 16,519. 
Penelitian ini menunjukkan hasil analisis uji chi-square yang dilakukan untuk menilai hubungan antara kadar HbA1c dengan tindakan amputasi ektremitas pada pasien ulkus kaki diabetes memperoleh nilai $\mathrm{p}=0,024$. Dengan nilai $\mathrm{p}<0,05$, hasil ini menujukkan bahwa secara statistik terdapat adanya hubungan antara kadar HbA1c dengan tindakan amputasi ekstremitas pada pasien ulkus kaki diabetik.

Hasil penelitian ini sejalan dengan penelitian yang dilakukan oleh Pemayun et al. [8] mengenai faktor risiko amputasi ektremitas bawah pada pasien ulkus kaki diabetik yang dilakukan di Rumah Sakit Umum Pusat Dr. Kariadi Semarang. Dalam penelitian ini terdapat hubungan antara kadar HbA1c dengan tindakan amputasi ektremitas bawah dengan nilai $\mathrm{p}=$ 0,004 . Hasil yang sama juga didapatkan dalam penelitian Laclé \& Valero-Juan [19] mengenai insidens dan faktor risiko amputasi ektremitas bawah dengan pendekatan prospektif selama tujuh tahun di Costa Rica, menyatakan bahwa pasien yang memiliki kemungkinan paling besar untuk mengalami amputasi adalah pasien dengan kadar HbA1c $\geq 8 \%$ dengan nilai $\mathrm{p}=$ 0,001 .

Secara teori kadar HbA1c secara langsung berhubungan dengan rerata kadar glukosa selama masa hidup hemoglobin. Dengan mengontrol kadar HbA1c, perkembangan neuropati diabetik dan penyakit arteri perifer yang merupakan faktor risiko amputasi ektremitas dapat dicegah [20]. Selain itu kadar HbA1c yang tinggi menyebabkan pasien ulkus kaki diabetik lebih rawan terhadap infeksi [21].

Namun hasil penelitian ini tidak sejalan dengan penelitian yang dilakukan oleh Rodrigues, Vangavet, \& Usman [22] yang menyatakan bahwa rerata kadar HbA1c pada pasien yang melakukan amputasi lebih tinggi dibanding pasien yang tidak melakukan amputasi tetapi tidak signifikan secara statistik dengan nilai $p=0,92$.

Perbedaan hasil penelitian bisa diakibatkan oleh kadar HbA1c subjek dari penelitian hanya dapat menggambarkan kontrol glikemik pada pasien diabetes selama beberapa bulan terakhir, namun ulkus kaki diabetik adalah proses patologi yang panjang. Setelah menerima perawatan intensif, efek buruk dari kontrol diabetes yang kurang baik pada saat dimulainya penelitian kemungkinan diimbangi oleh perawatan tersebut [23]. Selain itu hasil pemeriksaan kadar HbA1c dapat dipengaruhi oleh kelainan genetik (thalasemia dan berbagai varian hemoglobin), kondisi klinis dengan perubahan usia dan jumlah eritrosit serta kadar hemoglobin [24].

Penelitian ini memliki keterbatasan yaitu peneliti hanya mengambil sampel ulkus kaki diabetik dengan diabetes melitus tipe 2 sehingga penelitian ini tidak menggambarkan hubungan pada pasien ulkus kaki diabetik dengan diabetes melitus tipe 1. Pasien yang datang ke RSUD Abdul Wahab Sjahranie Samarinda adalah pasien dengan ulkus kaki diabetik dengan tingkat wagner 3-5, jarang pasien datang dengan tingkat wagner di bawah itu dikarenakan tempat penelitian adalah rumah sakit rujukan nasional kelas $\mathrm{A}$.

\section{Kesimpulan}

Berdasarkan penelitian ini, maka dapat disimpulkan bahwa terdapat hubungan antara penyakit arteri perifer dan kadar HbA1c dengan tindakan amputasi ekstremitas pada pasien ulkus kaki diabetik di RSUD Abdul Wahab Sjahranie Samarinda. Penelitian ini dapat dilanjutkan menggunakan metode penelitian lain seperti case-control dan cohort untuk menentukan perjalanan penyakit dan efek yang diteliti.

\section{Etik}

Komite Etik Penelitian Kesehatan RSUD Abdul Wahab Sjahranie Samarinda No. Etik: 300/KEPK-AWS/IV/2021.

\section{Konflik Kepentingan}

Tidak ada

\section{Daftar Pustaka}

[1] PERKENI. (2015).Konsensus Pengelolaan dan Pencegahan Diabetes Melitus Tipe 2 di Indonesia. Jakarta: PB PERKENI.

[2] American Orthopaedic Foot \& Ankle Society. (2016). Diabetic foot ulcer. OrthopaedicsOne Articles.

[3] Ibrahim, A., Jude, E., Langton, K., Jesus, F. R. M.D., Harkless, L. B., Gawish , H., Huang, Y. Y., Labovitz, J., Xu, Z., Pendsey, S., Liu, F., Sadikot, S. \& Cho, N. H. (2017). IDF Clinical Practice 
Recommendations on the Diabetic Foot. Brussels: The International Diabetes Federation.

[4] Nurhanifah, D. (2017). Faktor-Faktor yang Berhbungan dengan Ulkus Kaki Diabetik. Healthy-Mu Journal, 1(1), 32-33.

[5] Farzamfar, B., Nazari, R. \& Bayanolhagh, S. (2013). Diabetic Foot Ulcer. Croatia: InTech.

[6] Frykberg, R. G., Wukich, D. K., Kavarthapu, V., Zgonis, T. \& Paola, L. D. (2019). Surgery for the diabetic foot: A key component of care. Diabetes Metab Res, 36(S1).

[7] Kennon, B. (2013). Is there a place for elective therapeutic amputaton in diabetic foot care?. The Diabetic Foot Journal, 16(2).

[8] Pemayun, T. G. D., Naibaho, R. M., Novitasari, D., Amin, N. \& Minuljo, T. T. (2015). Risk factors for lower extrimity amputation in patients with diabetik foot ulcers: a hospital-based case-control study. Diabetic Foot \& Ankle, 6(1).

[9] Bundó, M., Muñoz, L., Pérez, C., Montero, J., Montell, N. \& Torán, P. (2010). Asymptomatic peripheral arterial disease in type 2 diabetes patients: A 10-year follow-up study of the utility of the ankle brachial index as a prognostic marker of cardiovascular disease. Annals of Vascular Surgery, 24(8).

[10] Jude, E. B., Oyibo, S. O., Chalmer, N. \& Boulton, A. J. (2001). Peripheral Arterial Disease in Diabetic and Nondiabetic Patients: a Comparison of Severity and Outcome. Diabetes Care, 24(8).

[11] American Heart Association. (2012). What is peripheral vascular disease?. American Heart Association.

[12] Schteingart, D. S. (2006). Metabolisme Glukosa dan Diabetes Melitus, Patofisiologi, Konsep Klinis dan Proses Penyakit. Jakarta: EGC.

[13] Ugwu, E., Adeleye, O., Gezawa, I., Okpe, I., Enamino, M. \& Ezeani, I. (2019). Predictors of lower extremity amputation in patients with diabetic foot ulcer: findings from MEDFUN, a multi-center observational study. Journal of Foot and Ankle Research, 12(34)

[14] Welten, G. M., Schouten, O., Chonchol, M., Hoeks, S. E., Bax, J. J., Van Domburg, R. T. \& Poldermans, D. (2009). Prognosis of patients with peripheral arterial disease. The Journal of Thoracic Cardiovascular Surgery, 50(1).
[15] Aiello, A., Anichini, R., Brocco, E., Caravaggi, C., Chiavetta, A. \& Cioni, R. (2014). Treatment of peripheral arterial disease in diabetes: a consensus of the Italian Societies of Diabetes (SID, AMD), Radiology (SIRM) and Vascular Endovascular Surgery (SICVE). Nutrition, Metabolism \& Cardiovascular Disea ses, 24(4)

[16] Septiani, A. E., Rahardjo, S. S. \& Prasetya, H. (2020). Meta-Analysis of Risk Factors for Lower Extremity Amputation in Diabetes Mellitus Patients with Foot Ulcers. Indonesian Journal of Medicine, 5(4).

[17] Beaney, A. J., Nunney, I., Gooday, C. \& Dhatariya, K. (2016). Factors determining the risk of diabetes foot amputations - A retrospective analysis of a tertiary diabetes foot care service. Diabetes Research and Clinical Practice, 114, 69-74.

[18] Sastroasmoro, S., Gatot, D., Kadri, N. \& Pudjiarto, P. S. (2014). Dasar-dasar Metodologi Penelitian Klinis Edisi Ke-5. Jakarta Timur: Sagung Seto.

[19] Laclé, A. \& Valero-Juan, L. F. (2012). Diabetesrelated lower-extremity amputation incidence and risk factors: a prospective seven-year study in Costa Rica. Rev Panam Salud Publica, 32(3).

[20] Zhou, Z. Y., Liu, Y. K., Chen, H.L., Yang, H. L., \& Liu, F. (2015). HbA1c and Lower Extremity Amputation Risk in Patients With Diabetes: A Meta-Analysis. The International Journal of Lower Extremity Wounds, 14(2).

[21] Sadriwala, Q. S., Gedam, B. S. \& Akhtar, M. A. (2018). Risk factors of amputation in diabetic foot infections. International Surgery Journal, 5(4).

[22] Rodrigues, B. T., Vangavet, V. N. \& Malabu, U. H. (2016). Prevalence and Risk Factors for Diabetic Lower Limb Amputation: A ClinicBased Case Control Study. Journal of Diabetes Research, 2016(5941957).

[23] Lin, C., Liu, J., \& Sun, H. (2020). Risk factors for lower extremity amputation in patients with diabetic foot ulcers: A meta-analysis. PLOS ONE.

[24] Suryaatmadja, M. (2013). Peran pemeriksaan kadar HbA1c pada pengelolaan penderita diabetes melitus. Summit Diagnostic Update, 9(Q1). 